\title{
MUSICAL ARTIST'S TALENT STRUCTURE: IMMANENT MUSICAL AND PROFESSIONAL AND ORGANIZATIONAL MODUSES
}

\section{Ohanezova-Hryhorenko O.}

\section{INTRODUCTION}

According to the intonational concept of B. V. Asafiev, musician's sensory experience is an auditory experience: "... the source, the culture of musical hearing, composing and performing - everything is created and directed as communication of sound and pronunciation of music as sense" ${ }^{1}$. That is why, for the analysis of the talent structure of the singer and performer, whose main artistic language is musical and intonational expression, we define musical talent as the semantic basis of the creative process. D. K. Kirnarska in her work "Psychology of Special Abilities. Musical Abilities" offers a phylogenetic model of musical talent that has several levels, hierarchically, from the bottom up, reflecting the path of music and musical talent development throughout human history ${ }^{2}$. These include the following:

1. Intonational hearing is the most ancient layer of musical ability, reflecting a person's inclination for musicality, "the foundation of the ability to decipher the meaning of a musical message and to refer to it".

2. A sense of rhythm is an awareness of the reflexivity of a musical movement that shapes musical time, its emphasis and structure.

3. Analytical hearing - an awareness of the exact sound level in music - is the operating center of musical talent responsible for mastering musical language.

4. Architectural hearing - a sense of the musical text harmony, its proportionality and aesthetic integrity.

5. Musical and productive capacity is the supplier of ready-made "building blocks" for a given activity, the ability to use musical talent for the birth of an artistic product in a certain type of creative activity.

${ }^{1}$ Асафьев Б.В. Музыкальная форма как процесс. 2-е изд. Л. : Музыка, 1971. 376 c. C. 117.

${ }^{2}$ Кирнарская Д.К. Психология специальных способностей. Музыкальные способности. М. : Таланты - ХХІ век, 2004. 496 с. 


\section{General characteristics of talent model of the singer and performer}

Considering that the singer and songwriter's autopoiesis has a foreseen musical and intonational phenomenology, we take model of D. K. Kirnarska as the basis for the vocalist and singer's talent. The proposed structure in some ways reflects the professional algorithm of the singer's work on the musical image:

- Intonational modus - intonational hearing - the basic, archetypal level of sensory information perception.

- Rhythmic modus - sense of rhythm - structuring of primal sensory information in time and space: unit of structure in musical text - size, tempo, duration, semantic words and accents. The rhythmic modus is the "field" of the transition from unconscious impressions to conscious construction.

- Analytic modus - analytical hearing that provides the "linguistic ability" of the singer, vocabulary and grammar of his artistic language: vocal and performing (acting) skills.

- Architectonic modus - architectonic hearing - harmonization of all manifestations in the construction of a musical image - timbre of sound, its color and articulation.

- Musical and stage modus - musical and productive ability - autointerpretation of a musical image, defined by the ability to build a full-fledged musical image on the stage with its own voice, its evolution during the performance. The germs of this modus manifest themselves already at the level of intonational hearing, because the sensory reaction (subject to further analytical processing) is born on the basis of intonational impression. So, at the level of the primal modus - the intonational - the auto-interpretation of the musical image is being laid.

The substantive filling of the presented structure allows to conclude: the immanent moduses of the singer and performer's vocal and their sequential "absorption" reflect the philogenesis of the musical image. Schematically, this process can be represented as a model of the solar system, at the center of which there is the main, basic modus of talent - intonational, which implies the formation of the "orbits" of rhythmic, analytical, architectonic moduses and, accordingly, the most multilayered and allencompassing "orbit" of the musical and stage modus. The Centrifugal Power of the Solar System is the creative dominant that leads the vocalist and performer from the initial sensory impressions of the intonational modus to the full living of the musical image on stage at the level of the musical and stage modus. The centripetal force of the system is the intonational impression: as the primary source material of the creative professional process, it can affect any modus, even the farthest. The intonational modus sends its signals throughout the "web" of the creative process: there is no excitation in the 
environment, if there is no intonational impression. Given that thought, in order to become expressed in sound, becomes intonation ${ }^{3}$, we insist that intonation is a means of transferring sensual meanings from vocalist and performer to spectator. Thus, intonation is the beginning of the creative process and its result, the final "collection" of all work: the singer brings the semantic semantics of the musical image to the viewer through the timbral characteristics of his voice.

Intonational impression programs the future timbre colors of the musical image. The rhythmic sensation structures, "realizes" the intonational impression in the accents and intuitive agony of the vocal phrase. Due to the action of the analytical modus, the singer learns the vocal part, considering the stylistic features of the vocal language of the musical work, deliberately establishes the musical image character. Thanks to the action of the architectonic modus, the timbre and articulations of the musical image crystallize, in which the evolution of the musical image during the performance is traced. At the level of the musical and stage modus in the voice of the vocalist and performer his present personal experiences, his psychophysical state reflects - the level of the musical image resonance and personality of the vocalist and performer reveals.

The singer's basic ability is the intonational hearing, which is the main gestalt - the causative agent of the vocalist's nature performing aspect. The rhythmic modus is an ordering component that structures the sensory intonational impression and enables it to be processed at the level of already professional action. The analytical modus corresponds to the development of dramaturgy of the musical image - the analysis of the general idea of the work, the semantic load of a particular hero, his "inner action", and relations with other actors. The architectonic modus corresponds to the harmonization of the timbre "score" with the actors' tasks in different scenes and the supertask in the global musical dramaturgy of the play; therefore, it is a question of the organic and justified timbre changes of the character throughout the performance. The musical and stage modus of the vocalist and performer talent manifests itself as a quality and wholeness of the born musical image. This modus is responsible for performing as for the auto-interpretation - the singer's ability to combine his own mental construction and the mental construction of the musical image. Musical and stage modus highlights the degree of the musical image resonance and personality of the vocalist and performer, his ability to "exist" in the musical image "here and now".

The immanent multi-tiered linkage of the elements of the vocalist's performing talent reflects his synergy: "viability" and talent performance lies in his ability to organize himself. It is important that the talent structure is

${ }^{3}$ Асафьев Б.В. Музыкальная форма как процесс. 2-е изд. Л. : Музыка, 1971. 376 с. 
multiplicative, which means that if at least one component is zero, then all other components lose their value and the structure shatters ${ }^{4}$.

Therefore, in the talent structure of the singer and performer, the basic modus is intonational. We define intonational and rhythmic moduses as immanent musical, based on the basic feelings inherent to certain moduses. The selection and coordination of certain moduses help to clarify the activity of the musical and auditory consciousness of the singer: we define the intonational modus as a source of sensory impressions, and the ordering of these impressions, their awareness - as the field of the rhythmic modus activity.

The immanent creative process of the vocalist and performer is based on the intonational modus - as the defining structure-forming basis of his talent: the following moduses "blossom" and form the initial main impression of the singer - the intonational impression. The rhythmic modus, as an attempt to structure the intonational impression, allows to begin the process of awareness of its main semantic and energetic characteristics; analytical modus, aimed at the sound relations analysis, conducts professional analysis and builds a "skeleton" of musical image, based on musical impression; the architectonic modus collects the musical image, combining the musical impression of the vocalist and performer and the living of the musical image (implying timbral and articulatory "intonation"); the musical and stage modus completes the immanent creative process by experiencing the musical image "here and now".

Thus, the intonational modus permeates the entire talent structure of the vocalist. In synergistic terms, it can be said that the intonational modus determines the fractality of the talent structure - self-similarity, large-scale invariance, where fragments of the structure are repeated at different scales ${ }^{5}$. Any point of the system, as a fractal, embodies the properties of the whole system, that is, any modus of talent, any stage of the creative process, any competence - everything depends, everything is determined and can be restructured by the original intonational impression. In our opinion, fractality as a property of the system most accurately highlights the specifics of the creative process of the vocalist and performer as a phenomenon of nonlinear: the least middle impression can cause large-scale dissipation in the system and completely rebuild it. Intonational "arousal" at the level of any talent modus can cause a reorientation, reformatting the results of the whole system.

Thus, the structure of the vocalist and singer's talent is a reflection of the process of musical and intonational self-organization - the autopoiesis of the system: the intonational modus is also a strategic resource of the singer's

\footnotetext{
${ }^{4}$ Кирнарская Д.К. Психология специальных способностей. Музыкальные способности. М. : Таланты - XXI век, 2004. 496 с. С. 23

${ }^{5}$ Князева Е.Н., Курдюмов С.П. Основания синергетики. Синергетическое мировидение. Изд. 3-е, доп. М. :Книжный дом «Либроком», 2010. 256 с. (Синергетика: от прошлого к будущему). С. 221.
} 
talent - it programs the musical image as a complete musical and intonational artistic phenomenon, and a tactical tool - in fact, all professionalism of the performer is "fed" by the musical and intonational impressions.

\section{Immanent musical moduses of vocalist and singer's talent}

Intonational modus. Considering that music is "the art of intonated meaning" (B. Asafiev), we define intonational hearing as the basis of the autopoiesis of the vocalist and performer, an internal sensual form of awareness of the musical and dramatic material that shapes and directs the process of the singer's artistic thinking.

For example, V. K. Suhantseva insists that the emotion is intoned; the musical image is a deeply intonational image ${ }^{6}$.

According to L. P. Kazantseva, intonation, as the matrix of music, is "the smallest figurative and semantic element of music"

V. M. Kholopova thinks of intonations in music as of "figurative and semantic unity that exists in non-verbal-sound embodiment and functions through the experience of musical and semantic and extra-musical associative imaginations"8.

"Intonations are movements of the voice that come from the same movement of emotion, which is the most important factor in drawing the image" (S. L. Eisenstein).

Intonational hearing, according to D. K. Kirnarska, is an archetypal hearing for man: intonational hearing is the nerve of musical perception and creativity, the focus of liveliness and awareness of musical art"; "A property of hearing, specifically aimed at the perception of the emotional and semantic aspects of music" ${ }^{9}$.

Intonational hearing, in our opinion, is an artistic ability, because it not only allows us to perceive meaningful information through sound, but also to reproduce it, to create something new and to convey it to the viewer so that it is understood and comprehended. The singer's voice timbre is based on the ability of the intonational hearing to saturate the sound of musculoskeletal and visual and spatial associations, which, being psychologically attached to the sound, become very personal and intimate ${ }^{10}$. Musical material is not only a sound score, but above all a score of timbre, a score of semantic attraction.

${ }^{6}$ Суханцева В.К. Музыка как мир человека. От идеи вселенной - к философии музыки. К. : Факт, 2000. 176 с.

${ }^{7}$ Холопова В.Н. Теория музыкального содержания как наука. М. : Науч.-изд. центр «Московская консерватория», 2009. 24 с. С. 17.

${ }^{8}$ Холопова В.Н. Теория музыки : мелодика, ритмика, фактура, тематизм. СПб. : Лань, 2002. 368 с. : ил. (Учебники для вузов. Специальная литература). С. 22.

${ }^{9}$ Кирнарская Д.К. Психология специальных способностей. Музыкальные способности. М. : Таланты-ХХІ век, 2004. 496 с. С. 65.

${ }^{10}$ Ibid. C. 75 . 
The light and color decision of the performance, the choreographic decision of the performance, the timbre and orchestral decision of the performance - all these aspects of the embodiment of musical and dramatic material are "dictated" by the sharpness of the intonational hearing of the production group. It harmonizes and generalizes all the performance components of the singer's intonational hearing, which transforms not only his impression, but also all the above aspects. The images evoked by the music and predetermined by the actor's task come to life in the voice of the artist.

Intonational hearing plays an important role in mastering purely technical skills. The traditional approach to sound formation is rather limited. This approach limits the artist only to the anatomy and physiology of the vocal apparatus. It does not take into account the main source, the meta-basis of the singer's talent - intonational hearing.

In the process of reproducing the musical image, the singer's intonational hearing controls the vocal voice, acts as an internal cognitive instance, a source of sensory cognition of information. Also with the help of intonational hearing as a general basic ability, the singer's creative apparatus is able to harmoniously reproduce the entire technological process of performing on stage. It should be noted that this creative process takes place not only in the conscious sphere, but also actively uses the unconscious reserves of the artist's creative apparatus. There is something that controls the process of developing from a "parent" artistic organism a new living creation - a role-image. In our opinion, this is a professional skill of a musical artist whose elements are combined and interconnected on the basis of intonational hearing.

In the most general sense, the approximate path of the autopoiesis of the role-image is as follows: analysis of the information obtained by intonational hearing, assimilation, creation of a potential model of the future role-image, animation of this model by its artistic personality, the embodiment of a new living substance - the role-image on stage (occurring through the same mechanism of intonational perception, only the opposite - the colors of the artist's voice, his plasticity, caused by the actor's tasks, broadcast certain emotions of the role-image to the viewer and are recognized by him through the voice a plastic "intonational" role-image of the artist).

For the singer, intonational hearing is "a psychological mechanism for perceiving and deciphering meaningful parameters of music," deeply related to this particular activity; "meta-ability" that defines the structure and "triggers the motivational mechanism of talent" ${ }^{11}$. The singer's intonational hearing tends to "psychological theatricalization" ${ }^{12}$ : based on intonational impressions, the vocalist models the manifestations of his personality "in the proposed

${ }^{11}$ Кирнарская Д.К. Психология специальных способностей. Музыкальные способности. М. : Таланты-XXI век, 2004. 496 с. С. 96.

${ }^{12}$ Ibid. C. 75. 
circumstances" (K. S. Stanislavskyi's term) - in a certain musical way. Thus, one can conclude about the peculiar nature of the intonational hearing of the vocalist, who manifests his technological properties: he actively changes the timbral colors of the voice, even when the artist does not consciously do so: forcing the voice to work in the live actor's process of filling the sound with content and colors " here and now". Thus, intonational hearing for the vocalist remains the most acute, the most sensitive center of his artistic perception, which works as the main tool for reading the emotional evolution of the musical image.

Rhythmic modus. In the context of describing the stage-by-stage algorithm of being born a vocalist of a musical image, we are interested in the connection of rhythm and musical intonation in singer's creative thinking. Concerning the mechanism of the musician's creative process, we can conclude that rhythm is a certain psychological way of organizing the initial intuitive impression given by musical intonation in time and space.

Asafiev's intonational conception, according to which all elements of the musical process - harmony, mood, timbre, rhythm, orchestration, etc. are intonational, beyond intonation they are impossible, allows us to consider the rhythm not as an abstraction, but as an intonational core of music ${ }^{13}$.

V. M. Kholopova defined the unifying function of musical rhythm as a time and accent component of melody, harmony, texture, theme and all other elements of musical language ${ }^{14}$. For us, this understanding of the integrating function of rhythm allows us to analyze the rhythmic feeling of the singer as a certain "materialized" component of intuitive intonation.

B. M. Teplov characterizes the rhythm as the ability to actively experience music, which makes it possible to accurately feel the emotional expressiveness of the musical movement temporal crossing ${ }^{15}$.

Important in this regard is the opinion of Kirnarska, who emphasizes that the sense of rhythm is born from intonational hearing, it "grows out of it, but it grows, becomes more sophisticated, recording in a much more detail the process of movement that intonational hearing only feels whole"16; "If the intonational hearing reads the general meaning of the musical message, then the sense of rhythm is aware of its temporal organization, knowing the temporal relations of the sound elements" ${ }^{17}$. Concerning the specifics of the

${ }^{13}$ Асафьев Б.В. Музыкальная форма как процесс. 2-е изд. Л. : Музыка, 1971. 376 с. C. 312

${ }^{14}$ Холопова В.Н. Музыкальный ритм : очерк. М. : Музыка, 1980. 71с. : нот., схем. (Вопросы истории, теории, методики). С. 4.

15 Теплов Б.М. Психология музыкальных способностей / отв. ред. Э.А. Голубева, Е.П. Гусева, В.А. Кольцова др. М. : Наука, 2003. 379 с. С. 221.

${ }^{16}$ Кирнарская Д.К. Психология специальных способностей. Музыкальные способности. М. : Таланты-ХХІ век, 2004. 496 с. С. 105.

${ }^{17}$ Ibid. C. 104. 
singer's creativity, the general plan of the musical image is intuitively read on the basis of the intonational impression, and the rhythmic feeling is the tool of this intonational impression "objectification", an attempt to structure it and make it manageable.

Thus, we understand the intonational modus of a vocalist's talent as an unconscious impulse based on an intonational impression that initiates a professional algorithm. The rhythmic modus is the beginning of the process of realizing the intonational impression by deciphering its energy component. Thus, the intonational impression is "realized" through a rhythmic impression. Intonational and rhythmic impression is considered appropriate to combine "musical impression" into a single concept.

Musical impression is a reflection of the sensory experience caused by the interaction of immanent musical moduses of talent - intonational and rhythmic, the basic intuitive impression, and the "initial tool" of the vocalist's professional algorithm.

Despite the interaction and interdependence of the intonational and rhythmic moduses of the creative process, they have a sufficiently independent psychological origin and semantic purpose. At the same time, both moduses intonational and rhythmic - are considered as the initial level of musical information perception - a huge spectrum of feelings, including those that are not marked by the singer's personal experience, those which, according to O. F. Losev and V. P. Shestakov is characterized by a holistic, universal, primal, unconscious, intuitive impression born in the depths of the unconscious ${ }^{18}$. The following moduses of talent, which we consider to be the field of activity of the vocalist's professional consciousness, correspond to the harmony, symmetry, dimension of the musical image. Let us note only that, in our opinion, the rhythmic modus, being in its essence a separate independent modus, is a certain link - a "bridge" between the unconscious circle of intonational impressions and the conscious professional algorithm of the vocalist.

The authors of the recognized methodologies of the acting process in their works analyze the management of the mental and physical manifestations of human nature on the stage in terms of rhythm - internal and external, bearing in mind that action in the performing arts has two sides: mental and physical.

In this sense, we rely on the opinion of K. S. Stanislavskyi about the importance of the relationship between internal and external rhythms in the art of artist. The external rhythm - "visible, not just palpable" ${ }^{19}$ - is a form of

18 Лосев А.Ф., Шестаков В. П. История эстетических категорий. М. : Искусство, 1965. $375 \mathrm{c}$.

${ }^{19}$ Станиславский К.С. Собрание сочинений в 8 т. Т. 3 : Работа над собой в творческом процессе воплощения / ред. кол. М.Н. Кедров, О.Л. Книппер-Чехова, Н.А. Абалкин, и др. М. : Искусство, 1955. 500 с. С. 140. 
a certain plastic pattern that is perceived by sight. By internal rhythm the author understands the emotional state that is born under the influence of the proposed circumstances and determines the intensity of the experience of the artist, controls his behavior. K. S. Stanislavskyi asserted the emotional nature of the rhythm, determined the internal rhythm "not externally visible, but only internally felt" ${ }^{20}$.

M. O. Chekhov calls this same phenomenon not a rhythm, but a tempo, and also divides it into internal and external: internal tempo is defined as a fast (active) or slow (passive) change of images (thoughts), feelings and volitional impulses (desires); external tempo is expressed in fast or slow action ${ }^{21}$.

L. V. Grachova has the same opinion. She considers rhythm as a comprehensive characteristic of the actor's technological process and claims that the rhythm is subordinated to the whole chain of professional actions: "The rhythm of thinking is the "driver" of the rhythms of imagination and corresponding vegetative reactions" ${ }^{22}$. Attention is also given to feedback the rhythm of the music provokes certain emotional reactions ${ }^{23}$.

Therefore, we consider the sense of rhythm as a certain "compiler" of the singer's immanent creative process. The juxtaposition of the external rhythm is given by the musical material and the internal rhythm, which reflects the speed of the vocalist's psychophysical apparatus response to intonational impressions, proves the relationship and interaction between the artist's physical actions on stage and their psychological justification.

Paying attention to all mentioned above, we consider the sense of rhythm of the vocalist and performer to be a certain instrument of awareness the "objectification" of intuitive intonational impressions, which is determined by one of the main immanent mechanisms of the professional algorithm.

The sense of rhythm of the vocalist performer has a deep archetypal basis - it "sprouts" from the intonational hearing and expresses the expressive component of intonational semantics.

Considering the above and understanding of the musical impression as the original immanent basis of the singer's professional algorithm, we define the intonational and rhythmic moduses of the singer and performer's vocal as immanent musical moduses of his creative process.

20 Станиславский К.С. Собрание сочинений в 8 т. Т. 3 : Работа над собой в творческом процессе воплощения / ред. кол. М.Н. Кедров, О.Л. Книппер-Чехова, Н.А. Абалкин, и др. М. : Искусство, 1955. 500 с. С. 152.

C. 458.

${ }^{21}$ Чехов М.А. Путь актера. М. : АСТ : Транзиткнига, 2003. 554, [6] с. (Мемуары). ил. С. 74.

${ }^{22}$ Грачева Л.В. Актерский тренинг: теория и практика. СПб. : Речь, 2003. 168 с. :

${ }^{23}$ Ibid. C. 78. 


\section{Professional and organizational moduses of the vocalist and performer's talent}

Analytical modus. Analytical hearing is "language ability", vocabulary and grammar of a specific artistic language. The function of the analytical modus is detailing, professional fragmentation, and preparation of musical and dramatic material for its "processing" by the psychophysical apparatus of the artist.

Functional workload of the analytical modus of the vocalist's talent is a conscious use of professional competences.

The musical artist's analytical modus of talent reveals an affinity for analytical hearing as an "operating component of musical ability" ${ }^{24}$, which is able to consciously awaken, manipulate, and capture musical impressions.

Where intonational hearing and rhythm senses create a general contour of drawing and composition, analytical hearing imposes subtle shades of colors, strokes, undertones - it completes and completely paints a picture that intonational hearing and rhythm sensations have only delineated and outlined" 25 . It can be said that the sensory information received by the intonational hearing and "imparted" by the sense of rhythm, at the level of the analytical modus, is realized by the artist, structured and prepared for "implantation" of the artist's personality.

The analytical modus of the musical artist's talent is responsible for the conscious processing, fragmentation, structuring of the original musical and dramatic material, deciphering the author's conception of the character, his place in events, meaning and ideological load. This information is provided, on the one hand, by the author's lyrics - the score and the play, and on the other - by the artist's musical impressions received and learned at a subconscious level. Thus, it can be noted that due to the work of the analytical modus, a professional process is carried out at two levels:

- analytical information is disclosed and actions that require professional competencies are taking place;

- $\quad$ sensuous and musical sensory impressions of the artist are realized and "prepared" as an intuitive subconscious basis for revealing the semantic meanings of the author's material.

Given that the nature of analytical hearing is fully conscious and mindcontrolled $^{26}$, we consider the analytical modus as a professional stage of switching attention from the original intuitive impression to the conscious analysis of that impression. The essence of the process is in understanding the meaning of intuitive musical impression and preparing the psychophysical

${ }^{24}$ Кирнарская Д.К. Психология специальных способностей. Музыкальные способности. М. : Таланты-XXI век, 2004. 496 с. С. 214.

${ }^{25}$ Ibid. C. $139-140$.

${ }^{26}$ Ibid. C. 141. 
apparatus of the artist for mastering the author's text - adjusting to the stylistic author's language style, analyzing the director's decision of the role, performances in general, etc.

Given the specifics of the theatrical production, the same musical and dramatic material is performed on stage numerous times, thus raising the question of the artist's ability to adjust his psychophysical apparatus to work in a mode of constant repetition, and these repetitions relate to both physical and emotional manifestations. In our opinion, programming of the artist's ability to qualitatively repeat emotional experiences on stage occurs precisely at the level of the analytical modus of the creative process, because the ability to repeat emotions is based on the awareness of the origins of these emotions, the reasons for their occurrence. Thus, the evolution of repetitions (the rehearsal process) "accustoms" the psychophysical apparatus of the artist to certain schemes for controlling the occurrence of emotions. We find the confirmation of our conclusions at D. K. Kirnarska, who emphasizes the ability of analytical hearing to "control" the evolution of species of repetition ${ }^{27}$.

Generalizing the presented material, we determine the functions of the analytical modus of the vocalist and performer's talent:

- detailed analysis of the author's material;

- awareness and ordering of unconscious sensory information of intonational and rhythmic character, obtained from the author's material;

- "kneading" the proposed circumstances of the plot by his psychophysical apparatus;

- technological, at the level of professional competence, mastering the material by the artist.

Further, already during these repetitions, rehearsals and lessons, the psychophysical apparatus of the artist consciously becomes accustomed to the expression of the defined contents. In the process of this conscious "learning", the personal characteristics of the artist manifest themselves, and the originally designated "draft" of the role, acquires the "living meat" of the artist's personality. This stage of work is already at the level of the architectonic modus of the musical artist's talent.

Architectonic modus. The architectonic modus is the level at which the "enthronement" of the artist's personality takes place in the disassembled and prepared musical and dramatic material. At the analytical level, the artist outlines the horizontal plane of the role-image - by analogy with the intersection of the melody: builds a cross-cutting effect, voiced in timbre voice changes, plastic role score. At the architectonic level, the horizontal score of the role, like a skeleton, is accrued by the living tissues of the performer's personality.

${ }^{27}$ Кирнарская Д.К. Психология специальных способностей. Музыкальные способности. М. : Таланты-XXI век, 2004. 496 с. С. 140. 
The architectonic modus of the musical artist's talent, like the architectonic ear of a musician, brings together the whole concept of the roleimage: it is caused by the actor's tasks of "mutual pull-up" to the semantic unity of vocal, speech timbre and plastic. This process is possible only on live material - the personality of the artist. There is a vertical fabric of the roleimage that involves the implementation of "background plans" that can only be felt and revealed by the "performing artist" (who himself undergoes the transformation of his hero), unlike the "artist of the analyzing" (distant observer of character transformations at the analytical stage) preparation of musical and dramatic material of the role for assimilation). In the work of analytical and architectonic moduses, the overall talent of the artist is actively manifested as a specific unity of cognitive and emotional intellects ${ }^{28}$.

Musical and stage modus. Analytical, architectonic and music and stage moduses are characterized as professional and organizational moduses of creative process in the structure of the vocalist and performer because at the level of these moduses there is a conscious professional work on the organization of primordial musical impressions for the birth of a full-fledged musical image. The singer's professional work does not imply a clear division of conscious and unconscious spheres and their different existence at any stage of the creative process. The unethical consciousness of the artistic nature programs a constant interweaving of conscious and subconscious processes in creativity with different specific gravity at one stage or another. It can be said that, in a sense, the artist consciously "controls" the unconscious mechanisms of creativity. The point is, how much he is able to use analytical refinements to awaken unconscious processes, and how psycho-physical apparatus of the artist is capable of realizing the multilayered information of the unconscious reservoir of his personality. The so-called "fund of the unconscious" (A. S. Shvederskyi's term) is the main source of creativity, it provides the uniqueness of each product of creative activity, the originality of creative search. The more diverse the artist feels the connection between the phenomena of reality with one another, the higher is the variability and the ability to establish unexpected relationships, paradoxical interactions in the process of finding and achieving a specific artistic task ${ }^{29}$. The singer influences the viewer by "broadcasting his personality" as an active living subject of communication ${ }^{30}$. Thus, using the "subconscious" fund of his personality, the vocalist and performer acts as a subject of meaning for the viewer and for himself. We define personal experience as a singer of a musical

\footnotetext{
${ }^{28}$ Гоулман Д. Эмоциональный интеллект. Почему он может значить больше, чем IQ / пер. с англ. А.П. Исаевой. М. : Манн, Иванов и Фербер, 2013. 560 с.

29 Психология художественного творчества : хрестоматия / сост. К.В. Сельченок. Минск : Харвест, 1999. 752 с. (Библиотека практической психологии). С. 390.

30 Лютова С.Н. Марина Цветаева и Максимилиан Волошин : эстетика смыслообразования. М. : Дом-музей Марины Цветаевой, 2004. 192 с. С. 7-8.
} 
image as a multidimensional phenomenon, born of a professional algorithm of consciousness and unconscious mechanisms of creativity interaction. In view of this, we determine the essence of the next modus of the vocalist and performer's creative process.

Musical and stage modus is the actual stage presence of the singer on stage. Thanks to the action of the musical and stage modus, the vocalist and performer uses the emotional and meaningful "blocks" - gestures, intonations, behavioral and psychic manifestations of the invented musical image - born and prepared by the previous moduses, but already appropriated and "driven" through the personality of the singer himself. The structure of using these harvested "blocks" will be different each time - each performance on stage will be different from the previous ones. The phenomenology of this phenomenon is explained by the nature of the performing art itself - the "objectification" of the musical image "here and now", its birth through imagination, through the real feelings and thoughts of a living performer: each time the musical image on stage lives differently, depending on the psychophysical state of the performer at the moment, from the work of stage partners, the "breathing" of the audience, etc.

At the level of the musical and stage modus, the unconscious component of creativity comes to the fore: the performer is not afraid to let go of his consciousness as a means of self-control on the stage. The musical image lives on stage in the mode of autopoiesis - much like where a real person builds himself, manages himself. But such a "natural" auto-poetic condition of the invented substance is prepared by the previous professional work of all creative moduses.

\section{CONCLUSIONS}

The structural building of the vocalist's musical talent is a reflection of his professional algorithm:

- intonational and rhythmic moduses are a coherent natural unconscious foundation of talent;

- analytical modus is the stage of mastering musical and dramatic material through the use of professional competencies;

- architectonic modus is "incorporation" into the prepared structure of the musical image of the artist's personality;

- musical and stage modus is the experience of the musical image on the basis of the present psychophysical state of the performer, the level of manifestation of the creative and professional personality of the singer.

Intonational modus is the level of manifestation of meta-ability of the vocalist and performer - intonational hearing: the basis of musicality, synesthesia, and partiality of talent. Intonational hearing is understood as an internal cognitive instance - a sensual form of awareness of musical and 
dramatic material that directs the singer's thinking process. Intonational modus is understood as an unconscious impulse based on the intonational impression that initiates the professional algorithm of the vocalist.

Rhythmic modus is an awareness of intonational impression through deciphering its energy component. The sense of rhythm has a deep archetypal basis - it grows out of intonational hearing and expresses the expressive component of intonational semantics. At the level of the rhythmic modus of talent, intuitive intonational impression is "objected" through the rhythmic impression. We combine the intonational and rhythmic impression in a single concept - the musical (intonational and rhythmic) impression, which we consider to be the original sensory material of the professional process of the vocalist and performer. We characterize the intonational and rhythmic moduses of talent as immanent musical moduses of the creative process, the coordination of which helps to understand the activity of the musical and auditory consciousness of the singer and performer.

Analytical modus of the vocalist and performer's talent is the level of conscious use of professional competences, which involves switching attention from the original intuitive musical impression to conscious professional actions. The essence of the action at this stage lies in the preparation of the original author's material for assimilation of the singer's psychophysical apparatus and further modeling on certain principles of the musical image. This is a conscious analysis: processing of sensory impressions obtained from the author's material, mastering the voice of the vocal score; search for timbre colors of the voice, which is precisely this musical image, search for characteristics and articulations in the sound.

Architectonic modus of the vocalist and performer's talent is a stage of a professional algorithm, characterized by the "implantation" of the singer's personality in the prepared and "mixed" musical and dramatic material.

Musical and stage modus of the vocalist and singer's talent is grounded as an auto-interpretation, a state of resonance of the singer's personality with the musical image. Analytical, architectonic and musical and stage moduses of musical artist talent are characterized as professional and organizational moduses of creative process in the structure of musical artist's talent.

The intonational and rhythmic moduses of the musical artist's talent reflect the subconscious branch of the auto-poetry of the musical image; analytical, architectonic - the conscious work of the vocalist and performer's creative apparatus within the framework of the professional algorithm; the musical and stage modus "fuses" all the material of the previous moduses mastered by the creative apparatus of the vocalist and performer and embodies it on the stage "here and now".

The musical artist's talent structure is characterized by fractality and multiplicity. Fractality is ensured by the intonational sensitivity of the artist's 
psychophysical apparatus as the basis of his professional algorithm - "arousal" at the level of any modus causes the results of the whole system to be reformatted. The multiplicity of the musical artist's talent reflects the structural unity of the artist's professional algorithm - the absence of any modus hinders the professional process.

\section{SUMMARY}

The article presents the vocalist and performer's talent structure based on the phylogenetic structure of musical talent. All moduses are grounded not only as moduses of talent but also as immanent moduses of the vocalist and performer's creative algorithm. hearing.

The basic ability of the vocalist was determined by intonational

Intonational and rhythmic moduses are represented as immanent musical moduses, the function of which is to obtain and realize the original musical impression as the basis of the creative process of the vocalist and performer for the formation and reproduction of the musical image.

The analytical, architectonic and musical and stage moduses are grounded as professional and organizational moduses of the creative algorithm of the vocalist and performer, which involve conscious professional work of different levels, performed in a certain sequence and aimed at creating a musical image for professional stage performance.

\section{REFERENCES}

1. Асафьев Б.В. Музыкальная форма как процесс. 2-е изд. Л.: Музыка, 1971.376 с.

2. Гоулман Д. Эмоциональный интеллект. Почему он может значить больше, чем IQ. Пер. с англ. А.П. Исаевой. М.: Манн, Иванов и Фербер, 2013. 560 с.

3. Грачева Л.В. Актерский тренинг: теория и практика. СПб.: Речь, 2003. 168 с.: ил.

4. Кирнарская Д.К. Психология специальных способностей. Музыкальные способности. М.: Таланты-XXI век, 2004. 496 с.

5. Князева Е.Н., Курдюмов С.П. Основания синергетики. Синергетическое мировидение. Изд. 3-е, доп. М.:Книжный дом «Либроком», 2010. 256 с. (Синергетика: от прошлого к будущему).

6. Лосев А.Ф., Шестаков В. П. История эстетических категорий. М.: Искусство, 1965. 375 с.

7. Лютова С.Н. Марина Цветаева и Максимилиан Волошин: эстетика смыслообразования. М.: Дом-музей Марины Цветаевой, 2004. $192 \mathrm{c}$. 
8. Психология художественного творчества: хрестоматия. Сост. К.В. Сельченок. Минск: Харвест, 1999. 752 с.

9. Станиславский К.С. Собрание сочинений в 8 т. Т. 3. Работа над собой в творческом процессе воплощения. Ред. кол. М.Н. Кедров, О.Л. Книппер-Чехова, Н.А. Абалкин, и др. М.: Искусство, 1955. 500 с.

10. Суханцева В.К. Музыка как мир человека. От идеи вселенной к философии музыки. К.: Факт, 2000. 176 с.

11. Холопова В.Н. Теория музыкального содержания как наука. М.: Науч.-изд. центр «Московская консерватория», 2009. 24 с.

12. Холопова В.Н. Теория музыки: мелодика, ритмика, фактура, тематизм. СПб.: Лань, 2002. 368 с.

13. Чехов М.А. Путь актера. М.: АСТ: Транзиткнига, 2003. 554 с. (Мемуары).

Information about the author:

Ohanezova-Hryhorenko O.,

Doctor of Arts, Professor of the Department of Music History and Musical Ethnograph, Odessa National A. V. Nezhdanova Academy of Music 63, Novoselskogo str., Odessa, 65023, Ukraine 